\section{Efficacy of the Press Extraction Method for Bedding Plant Plug Nutrient Monitoring}

\author{
Holly L. Scoggins ${ }^{1}$, Douglas A. Bailey ${ }^{2}$, and Paul V. Nelson \\ Department of Horticultural Science, Box 7609, North Carolina State \\ University, Raleigh, NC 27695-7609
}

Additional index words. saturated media extract, soilless media, soil testing, plug nutrition

\begin{abstract}
There is a need for a substrate testing method suited for plug plant production. Methods currently used by most growers and analytical labs include the saturated media extract (SME) and the 2 water : 1 substrate (v/v) suspension. These methods are not particularly well-adapted to plug production. The press extraction (PE) method has been developed as a simple and quick alternative to these methods. However, interpretive standards for chemical analysis of plug substrates do not exist for PE. This study was designed to provide the necessary correlations between these methods to allow for development of $\mathrm{pH}$, electrical conductivity (EC), and nutrient interpretive ranges for plugs. Plugs of begonia (Begonia $\times$ semperflorens-hybrida Hort.), impatiens (Impatiens walleriana Hook. f.), marigold (Tagetes erecta L.), petunia (Petunia $\times$ hybrida Hort. Vilm.- Andr.), salvia (Salvia splendens F. Sellow ex Roem. \& Schult.), and vinca (Catharanthus roseus $\mathrm{L}$.) were collected from commercial greenhouses and the substrate solution extracted with the PE, SME, and 1:2 methods. Plugs of begonia, celosia (Celosia argentea L. var. cristata (L.) Kuntze Plumosa Group), marigold, petunia, and vinca were grown with three fertilizer rates of 50,150 , and $250 \mathrm{mg} \cdot \mathrm{L}^{-1} \mathrm{~N}$. Shoots were harvested 30 days after planting and the solution was extracted from each flat using the three methods. For both experiments, PE EC was equal to or higher than the SME EC, and the pH was equal to or lower than the SME pH. The pH from the 1:2 was also similar to the PE. However, 1:2 EC results were consistently the lowest because of the dilution inherent in the 1:2 method. Interpretation ranges for $\mathrm{pH}$ and $\mathrm{EC}$ relationships were calculated to compare results from the $\mathrm{PE}$ with published sufficiency ranges for the $\mathrm{SME}$ and 1:2.
\end{abstract}

Bedding plant plugs are grown in a very limited substrate volume. Consequently, buffering potential and nutrient reserves are reduced (Fonteno, 1996). This is critical since many plant species grown as plugs are sensitive to high or low pH (Bailey et al., 1995) or high soluble salts (Styer and Koranski, 1997). A goal of substrate testing is to obtain samples that truly represent the pool of nutrients immediately available to the plant. Displacement of this root-zone solution without significant dilution is the basis of the press extraction method (PE). In the PE, sample trays are collected one hour after fertilizer is applied, the surface of the plug is pressed, and the expelled solution collected (Scoggins et al., 2000). Testing should proceed $1 \mathrm{~h}$ after fertilizer is applied for the most reliable results (Compton and Nelson, 1997). Plant uptake would be measurable after a longer

Received for publication 14 Aug. 2000. Accepted 6 Aug. 2001. The research reported herein was funded in part by the Fred C. Gloeckner Foundation, and the North Carolina Commercial Flower Grower's Association. Mention of products does not imply endorsement of this product over similar products by North Carolina State Univ. We gratefully acknowledge the technical assistance of Ingram C. McCall.

${ }^{1}$ Current address: Dept. of Horticulture, Virginia Tech, 301C Saunders, Blacksburg, VA 24061

${ }^{2}$ Current address: Dept. of Horticulture, Univ. of Georgia, 1111 Plant Science Bldg., Athens, GA 30601. period of time $(>2 \mathrm{~h})$. Too short a period of time $(<1 \mathrm{~h})$ between fertilizing and sampling may result in inadequate equilibration between the added nutrient solution and the substrate.

Current substrate tests used by growers and analytical laboratories for greenhouse crops are the 2 water : 1 substrate or 5 water : 1 substrate $(\mathrm{v} / \mathrm{v})$, the saturated media extract (SME), and the pour-through (Lang, 1996). These tests are used for $\mathrm{pH}$ and electrical conductivity (EC) determinations and nutrient analysis. These testing methods each have their own interpretive ranges for substrate $\mathrm{pH}$ and EC, which, especially for soluble salts measurements, are not interchangeable. The SME requires a vacuum source and the subjective judgement decision of how much water to add during the extraction (Warncke, 1986). The most common methods for testing soluble salt content is to mix two or five parts water with one part substrate (1:2 or 1:5) (Warncke, 1990). Moisture content of the substrate can be a source of variability as can the volume of substrate (Warncke, 1990; Lang, 1996; Nelson, 1998).

The low substrate volume/high root mass of plugs is also problematic. Separating the substrate from the root mass in the later stages of plug growth can be difficult. The PE does not require the plug to be removed from the tray. The PE is a logical replacement for the SME and 1:2 tests specifically for plugs because it is quick, inexpensive, and allows for determination of $\mathrm{pH}$ and $\mathrm{EC}$ (and potentially $\mathrm{NO}_{3}{ }^{-}$and $\mathrm{K}$ with specific ion meters) on site and within minutes (Fonteno et al., 1995). There are none of the subjective decisions associated with other methods as to volumes to measure or amount of water to add. The potential variation that could occur from different extraction pressures has been addressed and found to be insignificant (Scoggins et al., 2000).

Values obtained from different substrate testing methods have been compared using correlation coefficients and regression equations by several researchers including Warncke, 1990; Wright et al., 1990; Sonneveld, 1990; and Yeager et al., 1983. For example, if the $\mathrm{pH}$ values from $\mathrm{PE}$ are found to be highly correlated with the $\mathrm{pH}$ from the SME, the resulting regression equation can be used to predict any $\mathrm{pH}$ defined by the relationship. Previous experiments comparing the PE to the SME and 1:2 methods used soilless substrate only; no plants were grown (Scoggins et al., 2001).

The primary objective of this study was to determine the relationship between the PE and both the SME and 1:2 tests when performed on actively growing plugs. Based on these relationships, we wanted to derive interpretive ranges for substrate nutritional properties. These ranges could then be compared with previously published standards for the SME or 1:2.

In Expt. 1, we sampled a variety of bedding plant species and fertility regimes by collecting and testing plug flats from growers around the state. This was an economical and efficient way to obtain a variable population grown under a wide range of conditions. This variation can give a substantial, more accurate correlation when seeking a calibration curve to establish general comparisons among methods (W.H. Swallow, personal communication).

Expt. 2 was designed to assess the results of the PE in comparison to the SME and 1:2 under known conditions of fertilizer levels and plant species. With the resulting predictive equations, we sought to provide a bridge between the PE and SME tests, making it possible to apply information already gained with the SME procedure to the PE test.

\section{Materials and Methods}

Expt. 1. Bedding plant plug flats were collected from three commercial greenhouses in North Carolina, during Apr. 1998. Our testing population consisted of various cultivars of bedding plant plugs (begonia 'Ambassador Scarlet', 'Gin Rose', and 'Red Vodka'; impatiens 'Dazzler Pink', 'Tempo Burgundy', and 'Impact Rose'; marigold 'Janie Bright Yellow' and 'Hero Orange'; petunia 'Ultra Blue', 'Ultra Burgundy', and 'Double Madness Mix'; salvia 'Red Vista' and 'Hot Stuff Red'; and vinca 'Pacific Punch', 'Pacific Red', and 'Grape Cooler'). Plugs were at growth stages 3 and 4 in the production cycle (Styer and Koranski, 1997) 
and were all of good quality and uniformity. Flats were hydrated at the time of analysis by subirrigation with deionized water until container capacity was reached. The substrate solution was allowed to equilibrate for 30 $\mathrm{min}$. The solution was then extracted with the SME, 1:2, and PE. Sample sizes of 20 plugs for standard 288 trays and 10 plugs for Winstrip144 trays (Winstrip, Fletcher, N.C.) resulted in total substrate volume of $\approx 100$ $\mathrm{mL}$. Sampling by volume, instead of by weight, reduces variability caused by differing physical properties such as bulk density (total porosity, water-holding capacity) and moisture content of samples (Bunt, 1986). Substrate volumes from 50 to $100 \mathrm{~mL}$ are sufficient to overcome this variability.

For the SME, plugs were removed from each tray, the shoot was clipped off, and the substrate plug placed into a beaker. Deionized water was added while gently mixing until the sample was saturated to the point of "glistening," then allowed to equilibrate for 30 minutes. The sample was transferred to a Büchner funnel lined with filter paper (Whatman \#1), placed over a vacuum flask, and the solution removed under vacuum. The extracted solution $\mathrm{pH}$ and $\mathrm{EC}$ was then measured (EXTECH 695 pH/Conductivity Meter; Waltham, Mass.). To inhibit further nitrification of the $\mathrm{NH}_{4}{ }^{+}-\mathrm{N}$ present in the solution, 3.0 $\mathrm{N} \mathrm{HCl}$ was added to each sample to reduce the $\mathrm{pH}$ to $\approx 3.0$. Samples were then analyzed for $\mathrm{NH}_{4}{ }^{-}-\mathrm{N}, \mathrm{NO}_{3}^{-}-\mathrm{N}$ (Lachat Quik Chem 8000; Zellweger Analytics, Milwaukee), P, K, Ca, $\mathrm{Mg}, \mathrm{SO}_{4}^{-}, \mathrm{B}, \mathrm{Cu}, \mathrm{Fe}, \mathrm{Mn}$, and $\mathrm{Zn}$ (Plasma 2000; Perkin Elmer Corp, Norwalk, Conn.) content.

The 1:2 extraction method involved removing the plugs from the flat (as previously described) and placing them in a beaker. The plugs were gently broken up to determine approximate volume (varied depending on plug cell size) and deionized water was added at a rate of $2 \times$ the substrate volume as according to Lang (1996). Samples were stirred and allowed to equilibrate for $30 \mathrm{~min}$. The $\mathrm{pH}$ and EC electrodes were placed directly into the slurry. Nutrient analysis was not performed on the 1:2 samples as little information is available regarding interpretive standards for this method (Lang, 1996). For the PE, plug trays were held over a beaker as 10 or 20 (depending on tray type) of the remaining plugs were pressed to expel the solution. Once collected, $\mathrm{pH}, \mathrm{EC}$, and nutrient analysis were conducted on solution as with SME samples.

Each flat served as a replication. There were nine replications each for begonia, impatiens, petunia, and vinca, and six replications for marigold and salvia. Data were analyzed as a factorial with the solution extraction methods and species as the factors. Analysis of variance was performed for $\mathrm{pH}$, $\mathrm{EC}$, and nutrient concentrations (SAS Institute, Cary, N.C.). When model analysis showed a significant main effect or interaction, species and method means were compared by a mean separation procedure (Fisher's protected LSD). Correlation coeffi- cients were calculated between extraction methods for $\mathrm{pH}$ and $\mathrm{EC}$.

Expt. 2. Standard 288-cell plug trays were cut into 72-cell sections (cell volume 5.7 $\mathrm{cm}^{3}$ ) and filled with a commercial germination mix (4-P; Fafard, Anderson, S.C.). Trays were sown with celosia 'Century Red', impatiens 'Dazzler Red', marigold 'Atlantis Yellow', petunia 'Madness Midnight', and salvia 'Empire Red'. The treatments were arranged in a factorial design of 5 (species) $\times$ 3 (N-rates) in a randomized complete-block design with five replications on greenhouse benches. After true leaves appeared, plugs were subirrigated on a daily basis with $13 \mathrm{~N}-$ $0.86 \mathrm{P}-10.8 \mathrm{~K}-6 \mathrm{Ca}-3 \mathrm{Mg}$ (Peters Plug Special, Scotts, Marysville, Ohio) at 50, 150, and 250 $\mathrm{mg} \cdot \mathrm{L}^{-1} \mathrm{~N}\left(91.5 \% \mathrm{NO}_{3}^{-}-\mathrm{N}\right)$. Trays were irrigated with tap water every third subirrigation event. Fertilizer solution was used for the final subirrigation $1 \mathrm{~h}$ before testing.

At the completion of the experiment ( $30 \mathrm{~d}$ after planting) entire shoots ( $\geq 68$ shoots per tray) were harvested prior to solution extraction. Shoots were washed, dried at $70^{\circ} \mathrm{C}$, weighed, ground, and analyzed for nutrient content. Shoot $\mathrm{N}$ and $\mathrm{S}$ were determined with a CNS 2000 analyzer; P and K by ICP spectroscopy (both, LECO Corp., St. Joseph, Mich.). After shoots were harvested, SME, 1:2 method, and PE were performed on each tray as previously described. Levels of EC and $\mathrm{pH}$ measurements were recorded, then the PE and SME solutions were analyzed for nutrient content as in Expt. 1.

Data were analyzed as a split-plot with combinations of species $\times$ fertilizer rate as whole plots and the solution extraction methods as the subplots. When model analysis showed a significant main effect or interaction, species and method means were compared by mean separation procedure and rate means were subjected to trend analysis.

\section{Results and Discussion}

$p H$. Extraction method had a significant effect on solution $\mathrm{pH}$. The $\mathrm{PE} \mathrm{pH}$ averaged about 0.25 of a unit lower than SME pH in both experiments (Table 1). There were conflicting results regarding 1:2 $\mathrm{pH}$. The PE values were similar to $1: 2 \mathrm{pH}$ in Expt. 1, but lower in Expt. 2. Both dilution and how the measurement is taken can impact $\mathrm{pH}$ results (Lang, 1994). Nelson (1998) states the 1:2 $\mathrm{pH}$ level is expected to be slightly higher than the SME due to dilution of the hydrogen ions. However, Lang (1996) reported $\mathrm{pH}$ readings taken in the 1:2 slurry to be slightly lower than those taken after vacuum extraction of the solution with the SME. Our results in this and previous studies show $\mathrm{pH}$ measurements performed on the PE solution to be generally lower than the SME and lower or equal to the $2: 1$. This may have been due to the rehydration (hence dilution) of the plug flats necessary in Expt. 1 rather than the irrigation with fertilizer solution (Expt. 2). This points out the necessity of a consistent irrigation method prior to testing to reduce what is probably the main source of variability with the PE method.

In both experiments, plant species had a considerable effect on solution $\mathrm{pH}$, regardless of extraction method used (Table 2). This is expected, as bedding plants can modify substrate $\mathrm{pH}$ during growth (Bailey et al., 1995). For example, at the start of Expt. 2, substrate $\mathrm{pH}$ as measured with the $\mathrm{PE}$ was 5.5. Root zone $\mathrm{pH}$ for petunia increased to 6.2 (mean for all fertilizer treatments), though known to perform best at a lower $\mathrm{pH}$ (Bailey et al., 1995). The need to control pH according to species is best accomplished by testing each species, not pooling samples across species or making inferences for several crops based on testing one crop. Significant interactions among method, rate, or species were much smaller than the main effects for both $\mathrm{pH}$ and $\mathrm{EC}$.

Electrical conductivity. Extraction methods accounted for much of the variation in EC levels. In Expt. 1, the PE and SME EC were similar (Table 1). Again, this was probably because of the dilution that occurred because the plugs were freshly hydrated. Less water, hence less dilution, would have been added to form the SME slurry, resulting in little difference in dilution between the methods. In Expt. 2, the PE EC averaged from 0.1 to $0.25 \mathrm{dS} \cdot \mathrm{m}^{-1}$ higher than the SME, depending on species (Table 2). Electrical conductivity values for PE and SME were higher than the 1:2 values for both experiments. The PE produced the highest EC values of the three methods across all five species (Table 2). Species had a small but significant effect on EC in Expt. 2, illustrating the speciesdependent variation in nutrient uptake (van Iersel et al., 1998) (Table 2).

The relationships of both $\mathrm{pH}$ and $\mathrm{EC}$ levels measured by the three methods agreed with previous studies comparing solution

Table 1. Comparison for $\mathrm{pH}$ and $\mathrm{EC}$ among testing methods for saturated media extract (SME), press extraction method, (PE), and 1 substrate: 2 water $(1: 2)(\mathrm{v} / \mathrm{v})$; means include all species. Mean separation comparing methods within experiments (across columns) by LSD at $P=0.05$.

\begin{tabular}{lccrcc}
\hline \hline & \multicolumn{2}{c}{ Expt. 1 $^{\mathrm{z}}$} & & \multicolumn{2}{c}{ Expt. 2 $^{\mathrm{y}}$} \\
\cline { 2 - 3 } \cline { 5 - 6 } & $\mathrm{pH}$ & EC $\left(\mathrm{dS} \cdot \mathrm{m}^{-1}\right)$ & & $\mathrm{pH}$ & EC $\left(\mathrm{dS} \cdot \mathrm{m}^{-1}\right)$ \\
\hline SME & $6.3 \mathrm{a}$ & $0.5 \mathrm{a}$ & & $6.1 \mathrm{a}$ & $0.6 \mathrm{~b}$ \\
PE & $6.0 \mathrm{~b}$ & $0.6 \mathrm{a}$ & & $5.8 \mathrm{~b}$ & $0.7 \mathrm{a}$ \\
$1: 2$ & $6.0 \mathrm{~b}$ & $0.2 \mathrm{~b}$ & & $6.1 \mathrm{a}$ & $0.2 \mathrm{c}$
\end{tabular}

${ }^{2}$ Means includes all species $(n=48)$.

${ }^{y}$ Means include all species and fertilizer rates for comparison purposes $(\mathrm{n}=75)$. 
Table 2. Comparison among methods for saturated media extract (SME), press extraction method (PE), and 1 substrate : 2 water (1:2) (v/v) for $\mathrm{pH}$ and EC $\left(\mathrm{dS} \cdot \mathrm{m}^{-1}\right.$ ) by species (includes all fertilizer rates for experiment 2 ). Mean separation comparing methods by LSD at $P=0.05$ represented by lower case letters (down columns but within experiments).

\begin{tabular}{|c|c|c|c|c|c|c|c|c|c|c|c|c|c|c|c|}
\hline \multicolumn{8}{|c|}{$\mathrm{pH}$} & & \multicolumn{7}{|c|}{$\mathrm{EC}\left(\mathrm{dS} \cdot \mathrm{m}^{-1}\right)$} \\
\hline & Begonia & Celosia & Impatiens & Marigold & Petunia & Salvia & Vinca & & Begonia & Celosia & Impatiens & Marigold & Petunia & Salvia & Vinca \\
\hline & & & & & & & & Expt. 1 & & & & & & & \\
\hline SME & $6.4 \mathrm{a}$ & --- & $6.1 \mathrm{a}$ & $5.9 \mathrm{a}$ & $6.4 \mathrm{a}$ & $6.1 \mathrm{a}$ & $6.6 \mathrm{a}$ & & $0.4 \mathrm{a}$ & --- & $0.8 \mathrm{a}$ & $0.3 \mathrm{a}$ & $0.6 \mathrm{a}$ & $0.5 \mathrm{~b}$ & $0.5 \mathrm{a}$ \\
\hline PE & $6.1 \mathrm{~b}$ & --- & $5.9 \mathrm{a}$ & $5.7 \mathrm{a}$ & $6.1 \mathrm{~b}$ & $5.7 \mathrm{a}$ & $6.3 \mathrm{~b}$ & & $0.4 \mathrm{a}$ & --- & $0.9 \mathrm{a}$ & $0.3 \mathrm{a}$ & $0.7 \mathrm{a}$ & $0.6 \mathrm{a}$ & $0.5 \mathrm{a}$ \\
\hline $1: 2$ & $6.2 \mathrm{~b}$ & --- & $5.9 \mathrm{a}$ & $5.7 \mathrm{a}$ & $6.1 \mathrm{~b}$ & $5.7 \mathrm{a}$ & $6.3 \mathrm{~b}$ & & $0.2 \mathrm{~b}$ & --- & $0.4 \mathrm{~b}$ & $0.1 \mathrm{~b}$ & $0.2 \mathrm{~b}$ & $0.2 \mathrm{c}$ & $0.2 \mathrm{~b}$ \\
\hline & & & & & & & & Expt. 2 & & & & & & & \\
\hline SME & --- & $6.1 \mathrm{a}$ & $6.5 \mathrm{a}$ & $5.5 \mathrm{~b}$ & $6.5 \mathrm{a}$ & $5.8 \mathrm{a}$ & --- & & --- & $0.6 \mathrm{~b}$ & $0.5 \mathrm{~b}$ & $0.6 \mathrm{a}$ & $0.5 \mathrm{~b}$ & $0.7 \mathrm{~b}$ & --- \\
\hline PE & --- & $5.7 \mathrm{~b}$ & $6.3 \mathrm{~b}$ & $5.5 \mathrm{~b}$ & $6.2 \mathrm{~b}$ & $5.6 \mathrm{~b}$ & --- & & --- & $0.8 \mathrm{a}$ & $0.6 \mathrm{a}$ & $0.7 \mathrm{a}$ & $0.6 \mathrm{a}$ & $0.8 \mathrm{a}$ & --- \\
\hline $1: 2$ & --- & $6.1 \mathrm{a}$ & $6.3 \mathrm{~b}$ & $5.7 \mathrm{a}$ & $6.4 \mathrm{a}$ & $5.8 \mathrm{a}$ & --- & & --- & $0.2 \mathrm{c}$ & $0.2 \mathrm{c}$ & $0.2 \mathrm{~b}$ & $0.1 \mathrm{c}$ & $0.2 \mathrm{c}$ & --- \\
\hline
\end{tabular}

extracted from substrate samples without plants (Scoggins et al., 2001). Since SME is the predominant method used by analytical laboratories (Lang, 1996 and Nelson, 1998), we chose to predict PE values based on this method. Correlation coefficients from both experiments reflect a good predictive relationship between these methods (Table 3). Press extraction $\mathrm{pH}$ can be expected to be similar to or slightly lower than SME $\mathrm{pH}$ values (Fig. 1). Solution soluble salts extracted by the PE are higher than levels measured by the SME method.

For both experiments, mean $\mathrm{pH}$ values were within, but soluble salts levels below, published interpretation guidelines for SME and $1: 2[\mathrm{pH}$ of $5.5-6.5$ for either method (Lang, 1996); EC 0.75-1.99 and 0.25-0.75 $\mathrm{dS} \cdot \mathrm{m}^{-1}$ respectively (Styer and Koranski, 1997)] (Table 1). For Expt. 1, the time involved in transport coupled with the advanced plug growth stages of the samples and the use of DI water to rehydrate the plugs may have contributed to the relatively low levels of soluble salts and extractable nutrients.

Nutrient levels. Results were somewhat inconsistent between the two experiments. Average extracted levels of $\mathrm{NH}_{4}{ }^{+}-\mathrm{N}$ and $\mathrm{K}$ were lower with PE than with the SME in Expt. 1 (Table 4). Other PE-extracted nutrients were at levels equal to or greater than SME (Table 4). In Expt. 2, PE-extracted macronutrient levels were equal to or higher than but well-correlated with SME levels (Fig. 2). Previous comparisons of SME and PE methods on substrate macronutrient content yielded similar results (Scoggins et al., 2001). Also in Expt. 2, both PE- and SMEextracted $\mathrm{NO}_{3}{ }^{-} \mathrm{N}$ correlated well to the applied fertilizer N-rates ( $r$ value of 0.84 and

Table 3. Correlation coefficients between saturated media extract (SME), press extraction method (PE), and 1 substrate : 2 water $(1: 2)(\mathrm{v} / \mathrm{v})$ : includes all species (Expt. 1) and all species and rates (Expt .2).

\begin{tabular}{llcc}
\hline \hline & & $\mathrm{pH}$ & $\mathrm{EC}$ \\
\hline SME $:$ PE & Expt. $1^{\mathrm{z}}$ & 0.80 & 0.73 \\
& Expt. 2y & 0.80 & 0.84 \\
PE $: 1: 2$ & Expt. 1 & 0.94 & 0.79 \\
& Expt. 2 & 0.87 & 0.68 \\
SME $: 1: 2$ & Expt. 1 & 0.84 & 0.83 \\
& Expt. 2 & 0.92 & 0.75 \\
\hline
\end{tabular}

${ }^{2}$ Expt. $1 \mathrm{n}=48$.

${ }^{\mathrm{y}}$ Expt. $2 \mathrm{n}=75$.
0.81 , respectively) (data not shown). As previously reported, $\mathrm{PE}$-extracted $\mathrm{Ca}$ and $\mathrm{Mg}$ were nearly double the SME values in both experiments (Table 4) (Scoggins et al., 2001).

There was more agreement between experiments regarding the micronutrients $(\mathrm{Zn}$, $\mathrm{Mn}, \mathrm{Fe}, \mathrm{Cu}$ ); PE levels were consistently higher and ranged from 1.5 to $\approx 5 \times$ the $\mathrm{SME}$ levels (Table 4). Boron levels were similar or slightly lower for the PE. None of the plug species grown displayed visible micronutrient deficiency or toxicity symptoms. There is little if any research-based information avail-
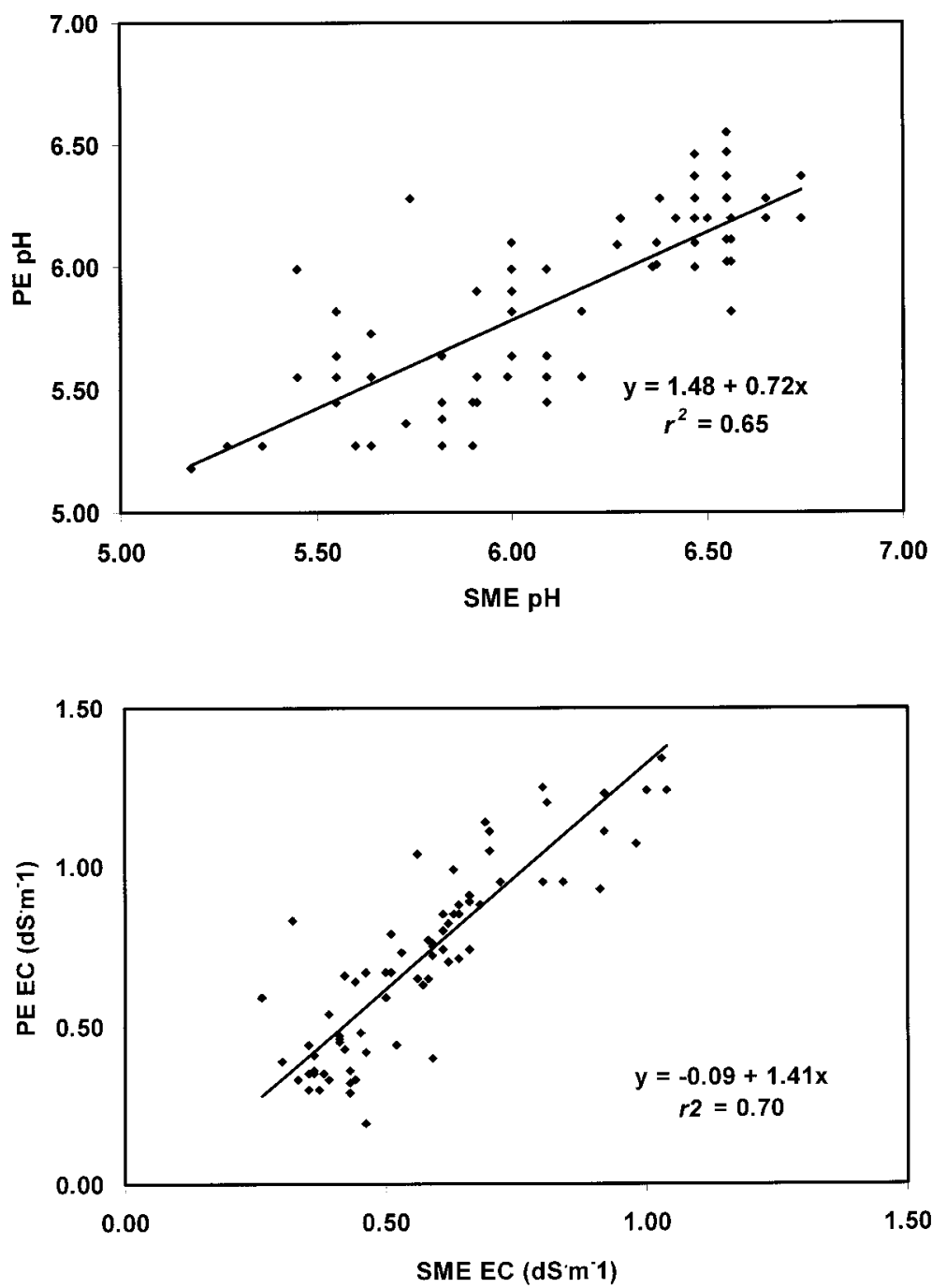

Fig. 1. Relationship between SME and PE pH and EC (Expt. 2) $(n=50)$. able regarding optimum micronutrient status and effects on plugs in soilless substrates (Warncke, 1990). Therefore, it is difficult to determine if test results fall within a sufficiency range, are toxic, or deficient. With PE, $\mathrm{EC}$ and nutrient levels can be expected to be slightly higher because the pressure displaces the actual substrate solution without the additional dilution necessary with SME.

The suitability of an extraction method for nutrient analysis should be considered. If the EC of a plug substrate exceeds recommended levels, it is important to identify 
Table 4. Comparison of nutrients extracted with the SME and PE: includes all species and rates.

\begin{tabular}{|c|c|c|c|c|c|c|c|c|c|c|c|c|}
\hline & $\mathrm{NH}_{4}^{+}-\mathrm{N}$ & $\mathrm{NO}_{3}{ }^{-} \mathrm{N}$ & $\mathrm{P}$ & $\mathrm{K}$ & $\mathrm{Ca}$ & $\mathrm{Mg}$ & $\mathrm{SO}_{4}^{-}$ & $\mathrm{Fe}$ & $\mathrm{Zn}$ & $\mathrm{Mn}$ & $\mathrm{Cu}$ & B \\
\hline & \multicolumn{12}{|c|}{$------------------\left(\mathrm{mg} \cdot \mathrm{L}^{-1}\right)---------------------$} \\
\hline \multicolumn{13}{|c|}{ Expt. 1} \\
\hline SME & $2.6^{*}$ & 18.0 & 4.1 & $39.5^{*}$ & 29.8 & 26.5 & 124 & 0.4 & 0.27 & 0.07 & $\mathrm{n} / \mathrm{a}^{2}$ & 0.18 \\
\hline PE & 0.8 & 14.6 & 3.5 & 23.9 & $58.9^{*}$ & $46.7^{*}$ & $212^{*}$ & $0.74^{*}$ & $1.36^{*}$ & $0.14^{*}$ & $\mathrm{n} / \mathrm{a}$ & 0.16 \\
\hline \multicolumn{13}{|c|}{ Expt. 2} \\
\hline SME & 1.9 & 39.1 & 7.2 & 51.2 & 37.9 & 23.5 & 82.7 & 0.71 & 0.18 & 0.08 & 0.71 & 0.10 \\
\hline PE & $5.1^{*}$ & $75.1^{*}$ & $13.1^{*}$ & $73.3^{*}$ & $71.0^{*}$ & $38.8^{*}$ & 80.7 & $0.83^{*}$ & $1.07^{*}$ & $0.26^{*}$ & $0.83^{*}$ & 0.08 \\
\hline
\end{tabular}

${ }^{2}$ Below detection limit.

*Means between SME and PE are significantly different (within each experiment); LSD at $\propto=0.05$.

which nutrient(s) are relatively high (Styer and Koranski, 1997). If the irrigation water is saline, this can contribute to accumulation of sodium and chloride and these elements should be included in analysis. Growers who use PE to obtain substrate solution for nutrient analysis need to take this information into consideration when adjusting fertility levels based on PE results. The strong relationships between PE and SME shown in Expt. 2 may encourage future work on the development of $\mathrm{N}, \mathrm{P}$, and $\mathrm{K}$ standards.

Foliar analysis. Regarding solution extraction methods, when pooling all species, percent foliar $\mathrm{N}$ did not correlate well with $\mathrm{NO}_{3}{ }^{-} \mathrm{N}$ extracted by either SME or PE ( $r=$ 0.35 and 0.33 , respectively), however, this relationship was stronger for some species than others (data not shown). This may be a function of the dilution effect on nutrient levels in rapidly growing plants. Van Iersel et al. (1998) noted that foliar analysis does not reflect current substrate nutrient levels. If fertilizer $\mathrm{P}$ and $\mathrm{K}$ levels are not deficient, they seldom correlate to tissue $\mathrm{P}$ and $\mathrm{K}$. However, a study of mature plants grown for a longer period of time under set fertilizer levels have yielded strong foliar N/extracted N correlations for other solution extraction methods (Wright et al., 1990). Though growers are urged by several sources to utilize foliar analysis for nutritional monitoring, there are no published sufficiency ranges for specific crops in the plug stage (Vetanovetz, 1996). Comparing samples from plants that appear to be suffering from nutritional disorders to tests from healthy plants is the current recourse. Dry weight increased for all species as fertilizer levels increased, so the fertilizer $\mathrm{N}$-rates were within a realistic range (data not shown).

Our data demonstrated reasonably consistent relationships between the extraction methods; particularly for $\mathrm{pH}$ and EC. The differences in results between Expt. 1 and Expt. 2 stress the need for consistency in how plugs are irrigated immediately prior to testing. Plug growers do not necessarily fertilize at every irrigation and this could be a significant source of variability when using the PE method-whether plain water or fertilizer was applied. The irrigation method used may also affect results. Research has shown that subirrigation can result in a buildup of salts in the upper third of the substrate in potted crops (Argo and Biernbaum, 1996). Whether this stratification occurs in the small volume of
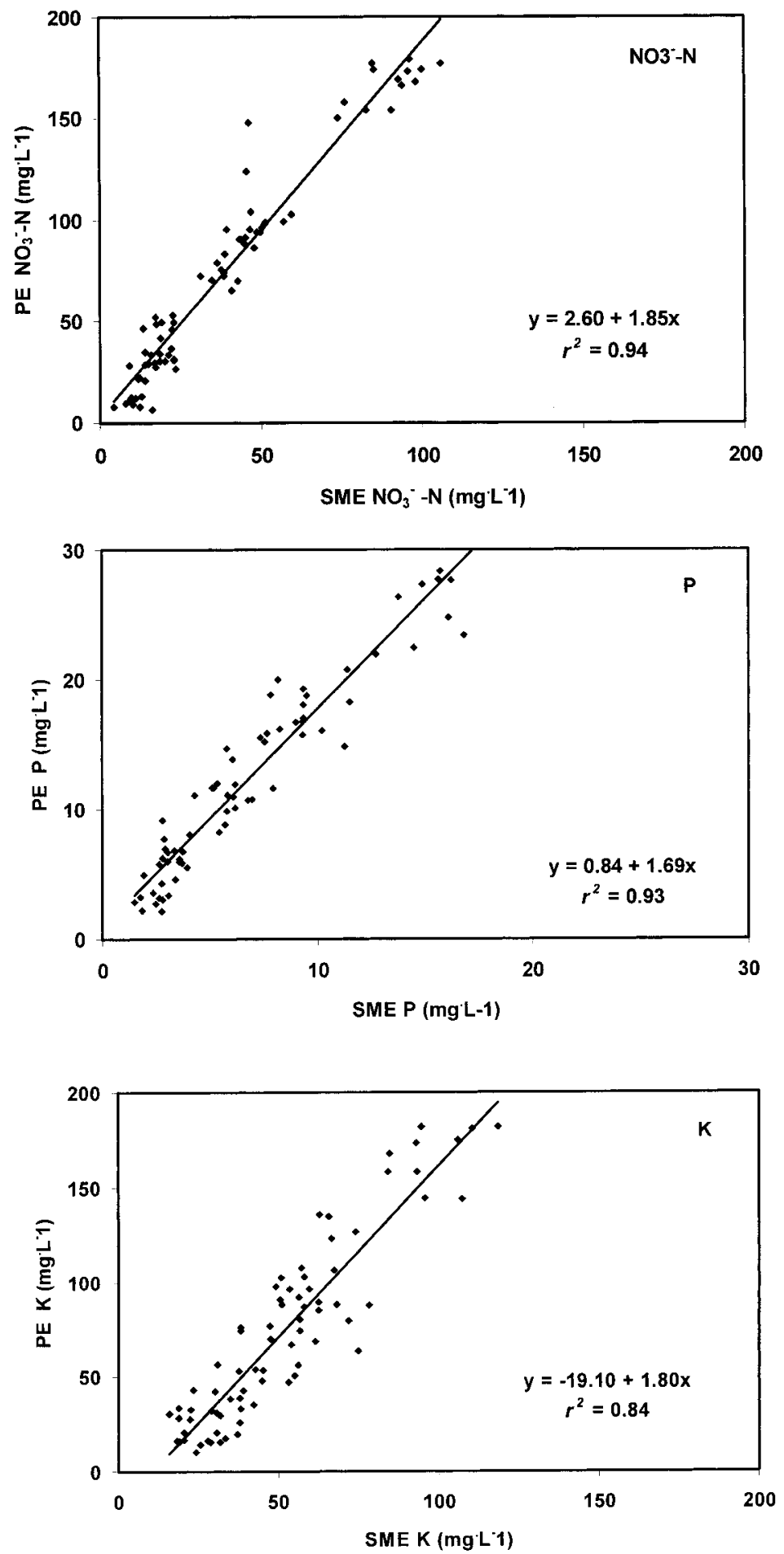

Fig. 2. Relationship between extracted solution levels of fertilizer nutrients nitrate-nitrogen $\left(\mathrm{NO}_{3}^{-}-\mathrm{N}\right)$, phosphorus (P), and potassium (K) for SME and PE (Expt. 2) $(\mathrm{n}=50)$. 
substrate associated with plug cells is not known.

Valuable information was gained in comparison of $\mathrm{pH}, \mathrm{EC}$, and nutrient analyses between SME and PE. Irrigation methods prior to testing have been identified as the main source of variability with the PE. Though more work is needed to establish crop-specific sufficiency ranges, the press extraction method has been established as a viable tool for plug substrate testing by greenhouse growers.

\section{Literature Cited}

Argo, W.R. and J.A. Biernbaum. 1996. Availability and persistence of macronutrients from lime and preplant nutrient charge fertilizers in peat-based root media. J. Amer. Soc. Hort. Sci. 121:453460.

Bailey, D.A., P.V. Nelson, W.C. Fonteno, J.W. Lee, and J.S. Huang. 1995. Plug pH-The make or break factor in nutrition. GrowerTalks 59(9):6, $8,10,12-13$.

Bunt, A.C. 1986. Problems in the analysis of organic and lightweight potting substrates. HortScience 21:229-331.

Compton, A.J. and P.V. Nelson. 1997. Timing is crucial for plug seedling substrate testing. HortTechnology 7:63-68.
Elliot, G.C. 1996. pH management in container media. Commun. Soil. Sci. Plant Anal. 27:635649.

Fonteno, W.C. 1996. Growing media: Types and physical/chemical properties, p. 93-122. In: D.W. Reed (ed.). Water, media, and nutrition for greenhouse crops. Ball, Batavia, Ill.

Fonteno, W.C., D.A. Bailey, and P.V. Nelson. 1995. Squeeze your plugs for simple, accurate nutrient monitoring. GrowerTalks 59(9):22, 24, 26-27.

Lang, H.J. 1994. Variation associated with testing procedures for $\mathrm{pH}$ and electrical conductivity of soilless potting media. HortScience 29:502.

Lang, H. J. 1996. Growing media testing and interpretation, p. 123-139. In: D.W. Reed. (ed.). Water, media, and nutrition for greenhouse crops. Ball, Batavia, Ill.

Nelson, P.V. 1998. Greenhouse operation \& management. $5^{\text {th }}$ ed. Simon \& Schuster, Upper Saddle River, N.J.

Scoggins, H.L.,P.V. Nelson, and D.A. Bailey. 2000. Development of the press extraction method for plug substrate analysis: Effects of variable extraction force on $\mathrm{pH}, \mathrm{EC}$, and nutrient analysis. HortTechnology 10:367-369.

Scoggins, H.L., D.A. Bailey, and P.V. Nelson. 2001. Development of the press extraction method for plug substrate analysis: Quantitative relationships between solution extraction techniques. HortScience 36:918-921.
Sonneveld, C. 1990. Estimating quantities of watersoluble nutrients in soils using a specific $1: 2$ by volume extract. Comm. Soil Sci. Plant Anal. 21:1257-1265.

Styer, R.C. and D.S. Koranski. 1997. Plug \& transplant production: A grower's guide. Ball, Batavia, Ill.

van Iersel, M.W., R.B. Beverly, P.A. Thomas, J.G. Latimer, and H.A. Mills. 1998. Fertilizer effects on the growth of impatiens, petunia, salvia, and vinca plug seedlings. HortScience 33:678-682.

Vetanovetz, R. P. 1996. Tissue analysis and interpretation, p. 197-220. In: D.W. Reed (ed.). Water, media, and nutrition for greenhouse crops. Ball, Batavia, Ill.

Warncke, D.D. 1986. Analyzing growth media by saturation extraction procedure. HortScience 21:223-225.

Warncke, D.D. 1990. Testing artificial growth media and interpreting the results, p. 337-357. In Soil testing and plant analysis, $3^{\text {rd }}$ ed. SSSA, Madison, Wisc.

Wright, R.D., K.L. Grueber, and C. Leda. 1990. Medium nutrient extraction with the pourthrough and saturated medium extraction procedures for poinsettia. HortScience 25:658-660.

Yeager, T.H., R.D. Wright, and S.J. Donohue. 1983. Comparison of pour-through and saturate pine bark extract N, P, K, and pH levels. J. Amer. Soc. Hort. Sci. 108:112-114. 